\title{
INVESTMENT STRATEGIES OF HOUSING DEVELOPERS IN LIGHT OF DEMOGRAPHIC CHANGES IN POLISH SOCIETY (SELECTED PROBLEMS)
}

\author{
Ewa Siemińska, prof. \\ Faculty of Economic Sciences and Management \\ Nicolaus Copernicus University \\ e-mail:ewahsiem@econ.umk.pl
}

\begin{abstract}
The main topic assumed in the deliberations of the present article is the phenomenon of dynamic changes in the demographic structure of the Polish society and their influence on the direction of changes in the development of selected aspects of the residential real estate market and its financing.

As it turns out, the increasingly evident aging of the Polish society, on the one hand, and high emigration of working-age youth, who set up families abroad, on the other, have their multidirectional determinants and implications also in the context of the residential real estate market. This interesting and relatively new - as far as the Polish economy is concerned - phenomenon requires a more in-depth diagnosis and analysis by various experts

Based on the newest available GUS, NBP, ZBP, BIK and KNF reports and statistics, as well as documents of developers, the development strategies of real estate development companies and the functioning of the banking sector engaged in financing the residential real estate market were analyzed in terms of their suitability to the occurring and forecasted demographic changes in society.

The aim of the study is to indicate the need to reduce the risk of developers' projects and entities engaged in servicing the real estate market by continuously adapting their offers to changing socioeconomic conditions.
\end{abstract}

Keywords: demographic, housing market, developer.

JEL Classification: R30, D00, D81, R31.

Citation: Siemińska E., 2016, Investment Strategies of Housing Developers in Light of Demographic Changes in Polish Society (Selected Problems), Real Estate Management and Valuation, Vol. 24, No. 2, pp. 72-84.

DOI: 10.1515/remav-2016-0015

\section{Introduction}

Dynamic changes taking place in the global as well as regional environment result in the necessity of different markets adapting to them (BOLEAT, COles 2012; GROSSE 2012; KALLAKMAA-KAPSTA, KOLBRE 2013). In Poland, similarly as to many other countries, progressing demographic changes in society, especially the progressing aging of the population and large scale of emigration, particularly concerning the young generation, as well as the migration of people to the largest urban agglomerations, mainly in search of work, are becoming more and more visible. On the other hand, demographic predictions of changes in the age structure leave no doubt that we are currently entering an intensive period of population aging, which in turn brings along the necessity of facing many new, and often previously not encountered challenges and phenomena in different spheres of activity including, among others, on the (not only) residential real estate market and in the financial sector. It turns out that the aging process of society has - in addition to the widely-understood social dimension - also an economic and financial dimension, without the knowledge of which it is difficult to talk about a rational and responsible reaction to the phenomenon. All of these changes influence the 
specific, varied in time and space, housing needs, which create factors which stimulate and destimulate the development of residential construction.

\section{Review of literature}

In Polish as well as foreign literature on the topic, much attention is given to the broadly understood processes of social changes, including demographic changes (e.g. KRÜGER 2016; IGLICKA-OKÓLSKA 2001; MANSFIELd 1980; EUROSTAT 2012; HeINZE, NAEGEle 2009; RUDNICKA, SuRdej 2013; PHILIPOV et al. 2014), as well as to real estate markets (e.g. LUMBY 1998; VOICU, SEILER 2013; KUCHARSKA-STASIAK 2006; BROWN 2015; DONNER 2000). However, there are not many works which connect these two aspects from the point of view of adapting investment strategies of developers present on the residential real estate market to the changing social realities, including those demographic (LUSARDI, MiTCHELL 2007; MCFADDEN 1994; FORYŚ 2011; RUDNICKA, SURDEJ 2013).

The aim of the new approach to the topic of demographic determinants of the development of the real estate market in Poland, with particular attention given to residential real estate, is firstly to clearly signalize a phenomenon that has not yet been adequately recognized in practice and science, and, moreover, to indicate the directions of further studies for deepening knowledge of aspects considered within the paper - studies that are not only economic but also interdisciplinary, including behavioral, connected with cultural anthropology or gerontology.

\section{Data and study methods}

Using rich statistical data from the end of the last century as well as current data, published by the Central Statistical Office (Główny Urząd Statystyczny - GUS), data from the Polish Financial Supervision Authority (Komisja Nadzoru Finansowego), and Polish Bank Association (Zwiąek Banków Polskich), as well as information on the topic of business strategies applied by selected real estate development companies in terms of their suitability to market needs, the paper presents practical examples of the directions taken by developers when investing on the Polish residential real estate market, especially when considering the demographic determinants of market demand.

The paper makes use of the comparative analysis method and expert method for diagnosing the above relations, as well as case study analysis. The results of the carried out studies are of a scientific nature that can also be applied in practice, as they can be used as indicators of the directions in which the developer segment of the real estate market shall look and develop, as well as contributing to more in-depth scientific studies regarding the complex and multithreaded dependencies occurring between demographic changes in society and the housing market.

\section{Outline of changes in the demographic situation in Poland}

According to the demographic forecast of the Central Statistical Office, the earlier initiated population decrease will become more pronounced along with the significant change in the age structure of Poles (Prognoza ludności..., 2014). It is estimated that, in 2050, the population count will not exceed 34 million people, thus will be lower than in the 2013 by approximately $12 \%$. At the same time, a greater decrease will pertain to the inhabitants of urban than rural areas, as in 2013, the former comprised nearly $60.45 \%$ of society, while in 2050 , their percentage is predicted to oscillate around $55.45 \%$ (Tab. 1).

Table 1

Current state and forecast of Polish population in the years 2013-2050 (state as of 31.XII in thous.)

\begin{tabular}{lcccc}
\hline & Actual Data & \multicolumn{3}{c}{ Forecast } \\
\cline { 2 - 5 } & 2013 & 2020 & 2040 & 2050 \\
\hline Total & 38495.7 & 38137.8 & 35668.2 & 33950.6 \\
\hline Urban & 23271.8 & 22716.6 & 20234.5 & 18825.8 \\
\hline Rural & 15223.9 & 15421.2 & 15433.7 & 15124.8 \\
\hline
\end{tabular}

Source: Population forecast for Poland for the years 2014-2050, Central Statistical Office, Warsaw 2014, p. 111.

The development of the population count and structure in a given country is influenced by many factors, especially the age structure of the society, the number of births (fertility rate), changes in longevity, the scale of migration, and many more. Due to the framework of the present paper, some of them have been briefly indicated below. 
One of these factors is the demographic structure of the population in Poland, which over the recent as well as forecasted years, has undergone and is expected to undergo radical changes. The progressing long-term decrease in the number of births, which was initiated after 1983, has made it difficult to make predictions regarding the process of rebuilding the population count in Poland without taking on long-term systemic measures. Moreover, in addition to the negative population growth, increasingly intense, unfavorable changes in the age structure of the population are observable. According to the mentioned forecasts, the number of people over the age of 65 in 2050 will have increased by 5.4 million as compared to 2013, and will comprise nearly $1 / 3$ of the entire population (Tab. 2).

Table 2

Population structure according to age groups in 2013 and 2050 (\%)

\begin{tabular}{lcc}
\hline Age & $\begin{array}{c}2013 \\
\text { Actual Data }\end{array}$ & $\begin{array}{c}\text { Forecast for 2050 } \\
\text { According to GUS base scenario }\end{array}$ \\
\hline $0-14$ & 15.0 & 12.1 \\
\hline $15-64$ & 70.3 & 55.2 \\
\hline $65+$ & 14.7 & 32.7 \\
\hline $85+$ & 1.6 & 6.1 \\
\hline
\end{tabular}

Source: Population forecast for the years 2014-2015, Central Statistical Office, Warsaw, p. 154.

Another factor which significantly influences the level and changes in the population is the scale of migration, both external and internal. According to the Central Statistical Office, at the end of 2014, approximately 2,320 thousand Polish residents were temporarily living abroad (Tab. 3), with the majority of them staying in EU member states (approx. 1901 thousand), especially Great Britain (685 thousand), Germany (614 thousand), Ireland (113 thousand), Holland (109 thousand), and Italy (96 thousand); (Information on the extent and direction of temporary emigration from Poland in the years 2004-2014, Central Statistical Office, Warsaw 2015). It is worth highlighting at this point that migration affects, for the most part, young Poles, who alone, or more and more often together with their families, settle in foreign countries, building their socio-economic position in a new environment.

Table 3

Estimate of emigration from Poland for temporary residence in the years 2004-2014 (number of people residing abroad at the end of the year in thous.)

\begin{tabular}{lccccccccccc}
\hline & 2004 & 2005 & 2006 & 2007 & 2008 & 2009 & 2010 & 2011 & 2012 & 2013 & 2014 \\
\hline Total & 1000 & 1450 & 1950 & 2270 & 2210 & 2100 & 2000 & 2060 & 2130 & 2196 & 2320 \\
\hline Europe & 770 & 1200 & 1610 & 1925 & 1887 & 1765 & 1685 & 1754 & 1816 & 1891 & 2013 \\
\hline UE (27 countries) & 750 & 1170 & 1550 & 1860 & 1820 & 1690 & 1607 & 1670 & 1720 & 1789 & 1901 \\
\hline
\end{tabular}

Source: Information on the extent and direction of temporary emigration from Poland in the years 2004-2014, Central Statistical Office, Warsaw, p. 3.

When looking at statistics illustrating the scale and direction of internal migrations in Poland, it is worth noticing the clear concentration of people in the largest Polish agglomerations, which results from the influx of young people looking for work and better living conditions. To serve as an example, over the past 25 years, Warsaw has changed from an "out-migration city" to an "in-migration city", similarly to Cracow or Wroclaw (http://www.polskawliczbach.pl). At the level of provinces, Pomorskie and Wielkopolskie provinces are worth noting, as they have, along with their largest agglomerations (Tricity and Poznan), exhibited a prevalence of in-migration over out-migration of inhabitants in the entire study period (1990-2014), as indicated by the ratio of in-and-out migration above unity (Tab. 4).

Such migrations within a country result in a concentration of housing needs in some places, with a clear weakening of such needs in others, which is not without influence on the development of local housing policy and investment decisions of entities responsible for the supply of various segments of 
the real estate market, especially residential (including for rental) and the widely understood urban infrastructure (Eco-innovations..., 2015, Innowacje w zarządzaniu..., 2014).

Table 4

Ratio of in-and-out migration according to in the individual provinces in the years 1990-2014

\begin{tabular}{lcccccc}
\hline Province & $\mathbf{1 9 9 0}$ & $\mathbf{1 9 9 5}$ & $\mathbf{2 0 0 0}$ & $\mathbf{2 0 0 5}$ & $\mathbf{2 0 1 0}$ & $\mathbf{2 0 1 4}$ \\
\hline Dolnośląskie & 0.94 & 0.99 & 0.98 & 0.97 & 1.05 & 1.07 \\
\hline Kujawsko-pomorskie & 0.93 & 0.97 & 0.98 & 0.94 & 0.94 & 0.93 \\
\hline Lubelskie & 0.87 & 0.92 & 0.89 & 0.82 & 0.81 & 0.79 \\
\hline Lubuskie & 0.98 & 1.01 & 0.96 & 0.97 & 0.96 & 0.95 \\
\hline Łódzkie & 0.95 & 0.96 & 0.95 & 0.94 & 0.93 & 0.93 \\
\hline Małopolskie & 0.96 & 1.02 & 1.09 & 1.11 & 1.13 & 1.13 \\
\hline Mazowieckie & 1.00 & 1.07 & 1.17 & 1.26 & 1.22 & 1.24 \\
\hline Opolskie & 1.06 & 1.00 & 0.99 & 0.94 & 0.94 & 0.93 \\
\hline Podkarpackie & 0.98 & 0.97 & 0.92 & 0.91 & 0.90 & 0.90 \\
\hline Podlaskie & 0.95 & 0.94 & 0.92 & 0.87 & 0.88 & 1.12 \\
\hline Pomorskie & 1.05 & 1.04 & 1.07 & 1.08 & 1.10 & 1.12 \\
\hline Śląskie & 1.29 & 1.10 & 0.96 & 0.94 & 0.93 & 0.92 \\
\hline Świętokrzyskie & 0.81 & 0.87 & 0.86 & 0.84 & 0.81 & 0.80 \\
\hline Warmińsko-mazurskie & 0.93 & 0.92 & 0.89 & 0.88 & 0.86 & 0.85 \\
\hline Wielkopolskie & 1.03 & 1.02 & 1.05 & 1.06 & 1.04 & 1.03 \\
\hline Zachodniopomorskie & 1.02 & 0.99 & 0.99 & 0.95 & 0.95 & 0.96 \\
\hline
\end{tabular}

Note: in-and-out migration indicators $>1$ have been marked in gray.

Source: Population forecast for Poland in the years 2014-2050, Central Statistical Office, Warsaw, 2014, p. 86; Internal and external migrations for permanent residence in the years 2010-2014, Central Statistical Office, Warsaw 2015.

At this point, it is worth noting the tendency of many inhabitants moving out from city centers to surrounding suburban neighborhoods, which is characteristic of many Polish cities; this, without analyzing at this point the conditions and reasons behind such decisions - implies certain consequences regarding the mutual and varied (not only in terms of communication) interrelations between the center of a given city and the neighboring towns, and the depopulation process, sometimes connected with the degradation of certain neighborhoods. Among the many examples, one can list the City of Poznan which has lost nearly 10,000 inhabitants, who have moved to the neighboring communes in the recent years.

Another important factor influencing demographic changes in society and the changes in housing needs connected with this, is the number of marriages entered into, their duration accounting for the number and age structure of children from such relationships, and number of divorces (FORYŚ I. 2011). According to the newest data of the Central Statistical Office, the number of marriages entered into in 2014 amounted to over 188 thousand, which, compared to the level from the '80s and '90s of the past century, i.e. on average 250 thousand per year, clearly indicates a constant decreasing tendency (Matżeństwa..., 2016). The moment of creating a household, connected with entering into marriage depending on the possible ownership of a house or apartment by one (or both) of the spouses - is most often the grounds for the emergence of new housing needs, comprising a component of the demand side of the market. A similar situation is observed in the case of a breakup or dissolution of marriage, with the difference that expectancies regarding housing depend on the number of people remaining in such a household as well as their age structure.

It is worth indicating at this point the fact that the decision of having a first child by women of reproductive age has been significantly postponed. Although this phenomenon is also characteristic of many economically developed countries, we must keep in mind that such behaviors are not without influence on the housing needs of a growing family. In Poland, the average age of having a first child in 1990 was at the age of 26.2 years, whereas in 2014 - 29.5 years (Prognoza ludności..., 2014; 
www.stat.gov.pl). The decrease in the number of marriages entered into and putting off the decision to have a first child have led to a decrease in fertility rate, which, from approx. 1.99 in the middle of the '80s of the XX century, fell to 1.29 in 2013 (Matżeństwa..., 2016).

At the same time, housing needs, though often of a different scale and structure as well as standard, are generated by single-person or two-person households, the number of which is continuously increasing, and which are becoming a more and more frequent occurrence among groups of young people choosing this type of lifestyle. The number of single-person households is also increasing among the elderly, which is connected, on the one hand, with increased longevity, and on the other - with the death of a spouse and the leaving of children who come from such a family (Małżeństwa..., 2016). In this situation, however, housing preferences change both for financial reasons connected with the costs of maintaining an apartment - often too high for a single seniorcitizen, along with what are often insufficient funds to live off of, as well as due to architecturalservice values, important especially when considering the various heath limitations of senior citizens.

\section{Investment strategies of developers on the housing market in Poland - selected examples}

Adapting their business strategies to the needs of the market, many developers offer various products in their investment portfolios dedicated to specific groups of clients. Such adaptation accounts for, above all, the financial abilities of the potential clients as well as their preferences in terms of key parameters connected with the location and use of real estate on offer.

Moreover, assistance programs connected with residential construction in effect, such as the "Rodzina na Swoim" (Family on its Own) and "Mieszkanie dla Młodych -MdM" (Apartment for the Youth) (MdM; Act of 2013...), which was introduced at the beginning of 2014 and planned until 2018, are not without influence. State programs, offering specific financial aid, are intended for only selected groups of beneficiaries and such types of residential real estate that fulfill specific functional and price parameters. The most common scenario is that the obligatory price limit for new apartments covered by the MdM program determines the location of the new investment (e.g. on the outskirts of a given city) and the standard of finishing. Therefore, developers, seeking competitive solutions, attempt to match at least part of their offer to the current requirements specified in legal regulations regarding housing subsidies in their business strategies in order to obtain those clients who can be the beneficiaries of such solutions. Their offer often pertains only to a few selected housing units in constructed multi-family buildings or residential housing complexes, and is treated by developers as a type of advertisement for the entire project. According to the newest statistics of the Bank Gospodarstwa Krajowego (National Economy Bank), people bringing up children took significant advantage of the financial aid for mortgages in the scope of the MdM program, which, in its essence, has a family-friendly nature. The highest percentage share of funding granted in 2015 went to married couples with one child (23.6\%), another $8.8 \%$ to married couples with three children, and $7.51 \%$ to those with two. Some of the aid was paid out to single parents (www.bgk.pl).

Depending on the scale of the company's operation and its position on the market, developers accept various operational strategies, beginning with relatively small investment projects of a local nature, up to investments realized in the area of the entire country and beyond - in the case of companies with strong capital, most often with a share of foreign capital, noted on the Stock Exchange. This group of developers, i.e. leaders, includes such companies noted on the Warsaw Stock Exchange as: J.W. Construction Holding S.A., Echo Investment S.A., Grobe Trade Centre S.A., Dom Development S.A., Erbud S.A., Robyg S.A., Ronson Europe NV, Capital Park S.A. and others.

A characteristic trend on the residential real estate market is new investments being most frequently concentrated in the largest Polish agglomerations with the highest level of turnover on the primary market (Warsaw, Krakow, Wroclaw, Tricity and Lodz). Despite the fact that investment land in or near these cities is often significantly more expensive than in other locations, the market potential measured by the scale of demand and the level of transaction prices is the deciding factor as to the supply of new housing projects being concentrated around the above-mentioned agglomerations. According to the newest JLL reports, in 2015, the transaction price of $1 \mathrm{~m}^{2}$ of land zoned for housing estates located in the city center of Warsaw was, on average, 2.2-4 thousand PLN per $\mathrm{m}^{2}$ of usable surface area of apartments, whereas in cities with over 400 thousand inhabitants - depending on the location - 550 to 1.6 thousand PLN per $\mathrm{m}^{2}$ of usable surface area of apartments. Many developers decide to situate housing estates of single- or multi-family housing outside the borders of the cities, on land belonging to neighboring communes, mainly due to much more competitive prices of investment 
properties, which are often twice or more cheaper than those located within the borders of the city (Rynek gruntów inwestycyjnych w Polsce, 2015).

Moreover, a common practice among developers is the so-called phasing of investment projects, or the building of housing estates in stages depending on the rate that the apartments offered in the scope of the first, survey stage of the given investment sold at. This is the so-called strategy of rational investment, the aim of which is especially to decrease the risk of incorrect investment decisions (e.g. projects of such real estate development companies as, e.g.: LC Corp, Matexi Polska, Home Invest, J.W. Construction Holding, Wawel Service, Polnord, ECO-Classic, Atlas Estates, Victoria Dom, Waryński S.A. Grupa Holdingowa, Activ Investment, Rafin, Dom-Eko and many more).

Depending on the level of market maturity and phase of the economic cycle, developers are more or less likely to apply various promotions and special offers for their clients. Currently, in connection with the large scale of demand on the residential real estate market and further investment plans, many developers are applying various kinds of incentives and promotions for potential clients (SIEMIŃSKA 2012). The most frequently applied promotions are based on temporarily lowering the prices of some apartments, especially the last ones up for sale, or offering the possibility of purchasing garages or storage space for attractive prices, finishing the unit within the purchase price of the apartment, agreeing on a payment plan that is convenient for the client, or providing access to cheaper notary services. Some developers, e.g. Dom Development S.A., ensuring the clarity of their offer, make it possible to access the Land and Mortgage Register for the registered property via the internet. In order to guarantee competitiveness and their position on the market, the majority of developers also declare the possibility of finishing the purchased apartment or house and delivering a turnkey product, usually in a choice of a few different standards depending on the preferences and financial capabilities of the client, most often offering an average, higher and highest variant of the package of finishing services.

Moreover, it is worth noting that the commonly applied standard in developer companies is providing the client with complete financial services. In addition to advisors who help chose the optimal apartment or house, financial advisors who are responsible for supporting clients in their choice and procedure of obtaining a bank mortgage necessary for realizing the purchase of real estate also play an important role. These solutions most often depend on the cooperation of the developer with financial advisors and intermediaries, who in turn collaborate with selected banks which offer loan products specially prepared for the developer's clients. The advantage of such a course of action is ensuring the client with the comprehensive support of a dedicated advisor over the course of the entire process of granting the bank loan, which no doubt has an influence on expanding the circle of potential buyers for apartments or houses offered by the developer.

Addressing the various market expectations of different potential groups of clients, many potential developers prepare a rich offer of various kinds of apartments and houses, from luxurious penthouses and apartments, the price and standard of finishing as well as location of which is at the highest level, and thus targeted towards very affluent clients, to apartments and houses complete to a higher standard, all the way down to popular standard module units from the segment of so-called compact housing, with lower floor areas and much more modest standard of finishing, but characterized by a functional layout which ensures the possibility of flexibly planning a few rooms (Inwestowanie w..., 2015). These types of dwelling are always popular, especially among clients whose limited budget does not allow for them to purchase a more expensive apartment, including young people just starting off on their own. The average floor area of an apartment purchased with subsidies from the MdM program was approximately 53-54 $\mathrm{m}^{2}$ in 2014 and 2015 (www.bgk.pl).

Within the assortment of their investment portfolios, developers more and more often propose socalled smart building solutions, using the newest innovational technologies, and guaranteeing safety and the highest comfort of living (BELNIAK et al. 2013). This in turn, does not remain without influence on the costs of maintaining such housing and, despite the fact that their price is higher than that of standard housing, there is not a lack of clients interested in also this segment of the market. The group of developers offering so-called smart houses includes, i.a.: Robyg S.A., Echo Investment S.A., Capital Park S.A., Millenium Inwestycje Sp. z o.o. Some buildings realized by developers contain what is referred to as "green certificates", such as BREEAM or LEED.

An interesting and experimental offer, as far as Polish conditions are concerned, is introducing socalled microapartments, with a floor area of $15-35 \mathrm{~m}^{2}$ on the market of the largest agglomerations with young singles in mind, who most often do not treat these as final but rather first own homes. The first 
of such kinds of units, built, i.a. by Spółki Dolnośląskie Inwestycyjne S.A. and POLNORD S.A., are being created in Wroclaw (the so-called STARTER I and II project), Warsaw, Gdansk, Krakow and Poznan. Sometimes they are purchased as investment apartments for renting out by various investors interested in investing their money in real estate.

Another strategy of some developers present on the Polish market is the realization of projects designated for rental. Some of these projects are offered within the framework of the Apartment for Rent Fund (Fundusz Mieszkań pod Wynajem), which is a commercial undertaking of the National Economy Bank (Bank Gospodarstwa Krajowego), while others, on the other hand, on the free market. Financial investments from the mentioned Fund are offered within the framework of what, in Polish conditions, is a novel model of institutional rent, the idea of which is to increase the availability of new apartments for rent in the biggest Polish agglomerations (ultimately, i.e. Warsaw, Krakow, Poznan, Wroclaw, Tricity, Katowice and Lodz), and thanks to this, improving the mobility of Poles (www.bgk.pl). As it has been assessed, housing projects for rent are mainly intended for the young generation who, upon gaining jobs and social independence, seek independent accommodation for a given, temporary period of time, most often connected with the time of studies or currently assumed job. The institutional rental sector in Poland is at the initial phase of development and comprises, for the moment, a small share of the market, with the largest interest exhibited by specialized investment funds (Wynajem mieszkań..., 2013).

A new housing trend on the Polish market is so-called senior-citizen construction, which is intended for the elderly, who often require additional care; thus, this kind of offer is sometimes supplemented with medical-nursing services. As it appears - in the context of earlier mentioned demographic forecasts - this segment of residential construction has very high potential, especially considering that the group of present and future senior citizens resides in dwellings which often do not possess a lift and other conveniences for the disabled, and the neighborhood of which often lacks the adequate infrastructure. Moreover, in addition to the observable changes taking place in the demographic structure of the Polish society, it is worth noticing the social model that has been undergoing changes for at least a few years, in which the traditional multi-generation family is less and less frequently encountered, especially in big agglomerations. The younger generation, in a race for success and career development, dedicates much more time to work than their parents, and more and more willingly contributes to what are often all too modest pensions in order to ensure their elders a better comfort and standard of living (Kompleksowa opieka..., 2016).

From the point of view of recognizing the housing needs of this group of clients, it is worth accounting for the changing physical and mental abilities as well as independence of senior citizens over time, and thus the type of preferred housing. Along the so-called "age axis", there is interdependence between the form of residence and type of senior services (BRZESKI et al. 2015):

- independent apartments intended for young seniors who are leading an independent active style of life, possessing facilities which make it possible to spend time actively.

- "serviced" apartments, which offer emergency domestic help and medical care, intended for mature seniors who require support,

- nursing homes intended for aged seniors, ensuring constant medical-nursing care and appropriate housing solutions.

Estimates indicate that, among the apartments sold in 2014 on the primary market by developers who are members of the Polish Association of Business Developers (Polski Zwiazek Firm Deweloperskich), approx. $3.5 \%$ of them were sold to seniors, which makes for 2.5 thousand apartments (BRZESKI et al. 2015). This is, therefore, a niche segment of the residential real estate market, though with high growth potential; this, however, is largely dependent on the institutional-legal conditions and economic solutions facilitating (or not) the development of widely understood infrastructure in the scope of senior policy which is necessary to implement in Poland. Some examples of investment projects connected with the so-called silver economy are, i.a. the senior citizen housing estate Niezapominajka near the city of Piła offered by the STA Developer Company, the Senior Residence facility in the Bażantowo housing estate near Katowice as well as further projects of senior houses planned by Millenium Inwestycje Sp. z o.o., the luxurious Vivante Senior Citizen Home constructed in Otwock near Warsaw by WI Vivante Fundusz Inwestycyjny, intended for people with a very high material status (in which the monthly cost of stay is over ten thousand zlotys), or a project termed "Angel Care" realized in Wroclaw along with the MD Nursing senior care center in Europe and developer group - Angel Poland Group (www.angel-care.pl). 
It is worth adding that, in this segment of residential real estate, the necessity of developers working together in order to come up with the best operating model of senior construction is more and more frequently indicated. An example of such activities at the meeting point of business and public entities are, i.a. Gliwice with a project called Centrum 50+ or the Opolskie Province, in which the pioneering Opolski Regional Senior Cluster (Regionalny Opolski Klaster Senioralny) was formed, aimed at creating space for a worthy and active lifestyle of the elderly part of society (Seniorzy w..., 2014, www.reas.pl).

At this point, it is worth noting the different opinions and views on the topic of senior citizen construction; some indicate the advantages of concentrated housing stock and senior-oriented infrastructure in one area, while others criticize such a premise, indicating the threat of the exclusion and stigmatization of neighborhoods intended solely for the elderly generation, and arguing for the necessity of social integration and the diversification of generations in various housing stock (BRZESKI et al. 2015; RUDNICKA, SURDEJ 2013).

\section{Selected financial determinants of demand on the residential real estate market}

At the conclusion of the presentation of the most important directions of investment strategies realized by development companies on the Polish residential real estate market accounting for demographic changes, it is worth at least mentioning - due to the framework of the present paper - the selected financial determinants of residential housing development which shape housing demand.

The scale and structure of housing demand is the result of housing (and/or investment) needs, to a large degree dependant on the availability of capital. Cyclic studies on the level and structure of sales on the real estate market show that, among others, so-called cash sales, which according to experts of the Polish National Bank (Narodowy Bank Polski) comprise anywhere from approx. 50\% in 2012 to nearly $65 \%$ in the III quarter of 2015 of the total value of all purchased apartments in the seven largest agglomerations of Poland ${ }^{1}$, have been systematically rising for at least the last few quarters (EASZEK et al. 2015). This is, therefore, locating capital in assets in what are deemed by the investor to be attractive - as compared to others - directions of investing (ŚMIETANA 2014). The majority of purchases, however, are realized at least in part by mortgage loans granted by various financial institutions. In the banking sector, the market of these loans continues to increase, though the rate of these changes has changed over the years (Fig. 1). The most important increases in volume of mortgages granted took place between the years 2006-2008, thus during the investment boom, and a clear hold back in the rate of changes, or what can even be referred to as stagnation in the level of mortgage debt, was observed in the years 2011-2012, when additional post-crises regulatory requirements were made to Polish as well as foreign regulators of the banking sector (compare e.g. SIEMIŃSKA 2013).

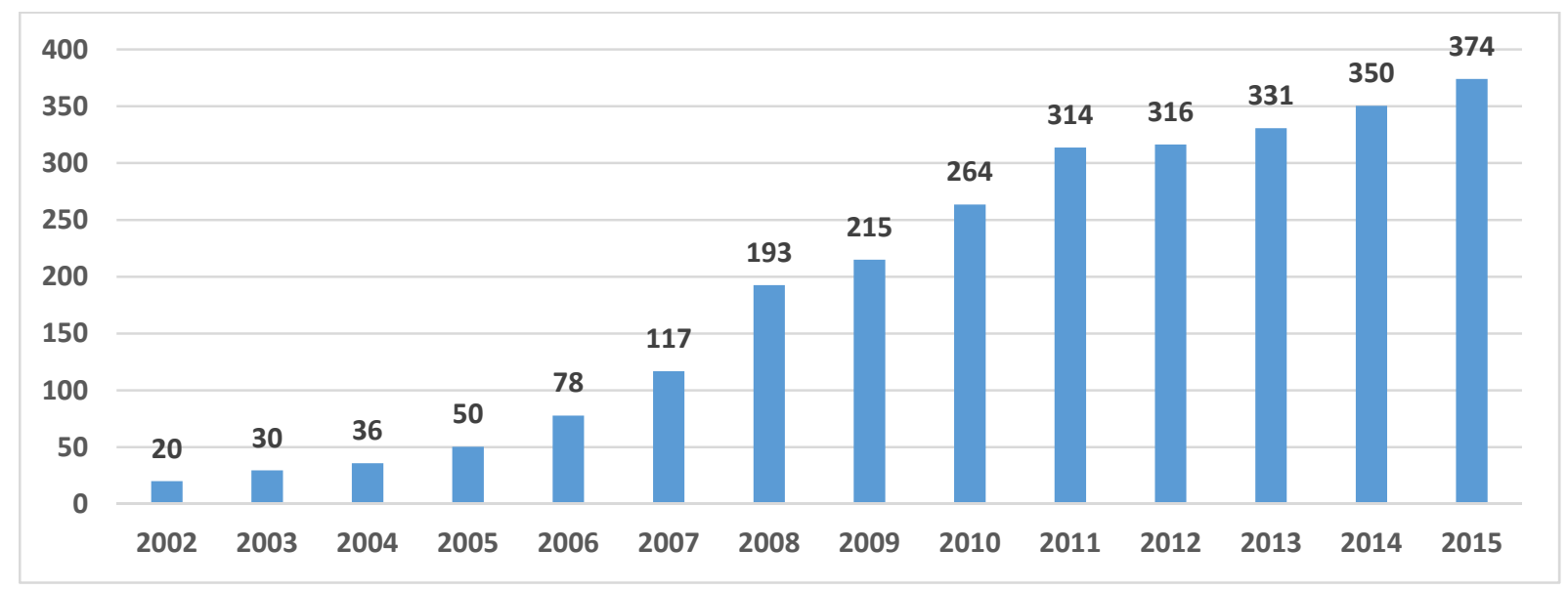

Fig. 1. Complete state of mortgage debt in Poland in the years 2002-2015 (billion PLN). Source:

Polish national report on mortgages and transaction prices of real estate from 2011 and 2015, AMRON-SAFRiN, www.zbp.pl; 25.01.2016.

Moreover, statistics show that the earlier mentioned instruments of financial aid aimed at supporting specific groups of beneficiaries in obtaining their own apartment influence, to various

1 i.e., Gdansk, Gdynia, Krakow, Lodź, Poznan, Warsaw and Wroclaw. 
degrees, the level of declared demand for construction. The announcement of the phasing out of a given program (end of 2012 for the Family on its Own program) or introducing significant changes to its parameters and assumptions (e.g. in the Apartment for the Youth program, expanding its scope, as of 2015, to include the secondary market) result in noticeable changes in the level of interest in taking out mortgages connected with a given program. For example, it turned out that the very announcement of the finishing of the Family on its Own program at the end of 2012 spurred some clients to make decisions regarding the purchase or building of a house or apartment financed with preferential mortgage, especially from the II half of 2011, though, at the same time, the changes introduced as of August 2011 in the regulations for granting subsidies to loans resulted in significant limitations in its application (Fig. 2). Similar fluctuations in the scale of financial aid in the scope of the Apartment for the Youth program are also visible in statistics regarding the number and value of loan agreements entered into with the support of the mentioned program. Approximately 31 thousand loan agreements, totaling over 5.5 billion PLN, have been granted as of 1 January 2014, with subsidies from MdM funds at the level of nearly 730 million PLN (Ogólnopolski raport o kredytach..., 2015, www.bgk.pl).

The year 2015 on the financial market was, for many reasons, very favorable to people taking out mortgages. Stimulants of the growing interest in taking out mortgages include a particularly low level of interest rates (level of reference interest rate in 2015 was 1.5\%), negative inflation indicators and relatively low bank margins (on average, at a level of approx. $2 \%$ ), as well as a rise in salaries (NBP, GUS 2015). Moreover, at the end of 2015, the announcement regarding the introduction of the socalled bank tax and concerns about bank margins being raised in connection with this, as well as the necessity of possessing a higher own contribution for the purchase of an apartment from the beginning of 2016 (at the level of 15\%), and, on one hand, expanding the availability of taking advantage of the MdM program to include the secondary market, but on the other - the fear of financial resources secured for the $\mathrm{MdM}^{2}$ program being prematurely exhausted, resulted in a significant increase in the demand for mortgages during this period (BŁASZCZAK, KRZEŚNIAKSAJEWICZ, 2016; BŁASZCZAK 2016).

12000000

60000

10000000

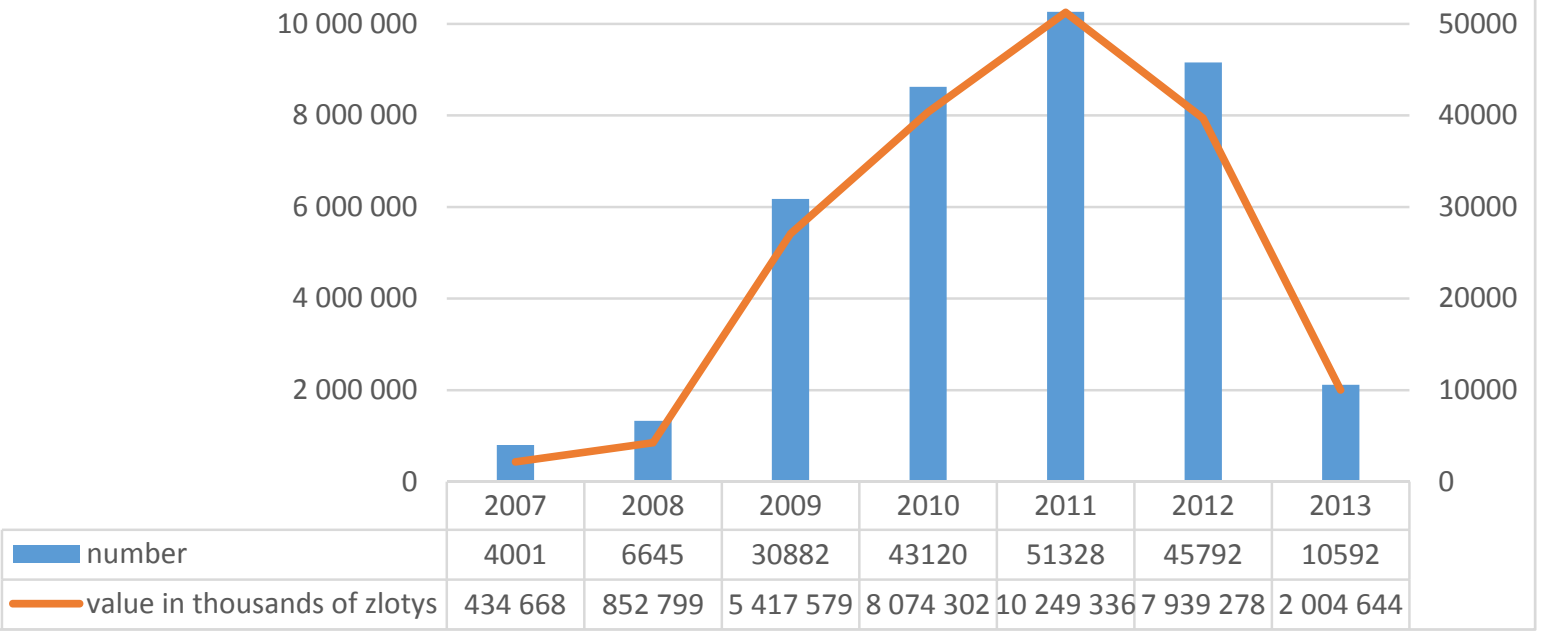

Fig. 2. Number and value of mortgages granted within the framework of the Family on its Own program in the years 2007-2013. Source: own elaboration on the basis of data: Rodzina na Swoim figures for 31.12.2013; www.bgk.pl (25.01.2016). In 2013, payments promised by banks up to the end of 2012 were paid out.

Against the background of selected general information regarding the financial determinants of the real estate market, it is worth at least briefly presenting a few examples of the demographic aspects of

\footnotetext{
2 The National Economy Bank in an official message on 15 March, 2016 informed that, due to 95\% of the funds set aside for supporting the purchase of an apartment (or house) within the framework of the MdM program for 2016 being exhausted, no new applications will be accepted as of 16 March, 2016 for subsidizing own contributions to be paid out in 2016 .
} 
financing the purchase of real estate by individual clients. It is, in fact, the very nature and inherent features of a mortgage that result in the fact that, as a rule, it should be granted to people who, thanks to the long timeframe of the loan agreement, will be able to pay off the obligation in whole. The age of the potential client is specified by the Polish Financial Supervision Authority (Komisja Nadzoru Finansowego) in recommendations for banks as one of the key, so-called qualitative features subjected to assessment when determining the creditworthiness of a retail client of a bank. "When assessing the term of a loan for a retail client, the bank should account for the ability of the borrower to produce income during the entire duration of the of the loan agreement, paying particular attention to the period in which the borrower can be expected to reach retirement age" (REKOMENDACJA S, 2013). In the structure of mortgage loans accounting for their time period they are granted, loans taken out for a 25-35 year period predominated. At the same time, the Committee of Financial Supervision, in its reports monitoring the situation of the banking sector, draws attention to the fact that, despite the binding provision of Recommendation $S$ on good practice regarding managing mortgage-backed credit exposures (REKOMENDACJA S, 2013), banks do not fully respect its provisions in their loan procedures regarding, e.g., recommending a 25-year repayment period for the loan to their clients, and, in practice, excessively extend this period for some loans, which leads to the period of the loan agreement extending well into the retirement-age of the borrower, or even exceeding average lifespans (Raport of sytuacji banków..., 2015). This, of course, results in a significantly higher risk of the loan not being paid off completely and thus, losses incurred by the bank. In this context, it is also worth indicating that, according to - not always easily accessible - data, the quality of the loan portfolio is relatively the worst among the group of the banks' oldest clients. The Credit Information Bureau (Biuro Informacji Kredytowej) reports that, along with the passing of time and so-called "aging" of mortgages, the elderly part of borrowers (over 65 years in age) has more and more problems with paying them off (Fig. 3).

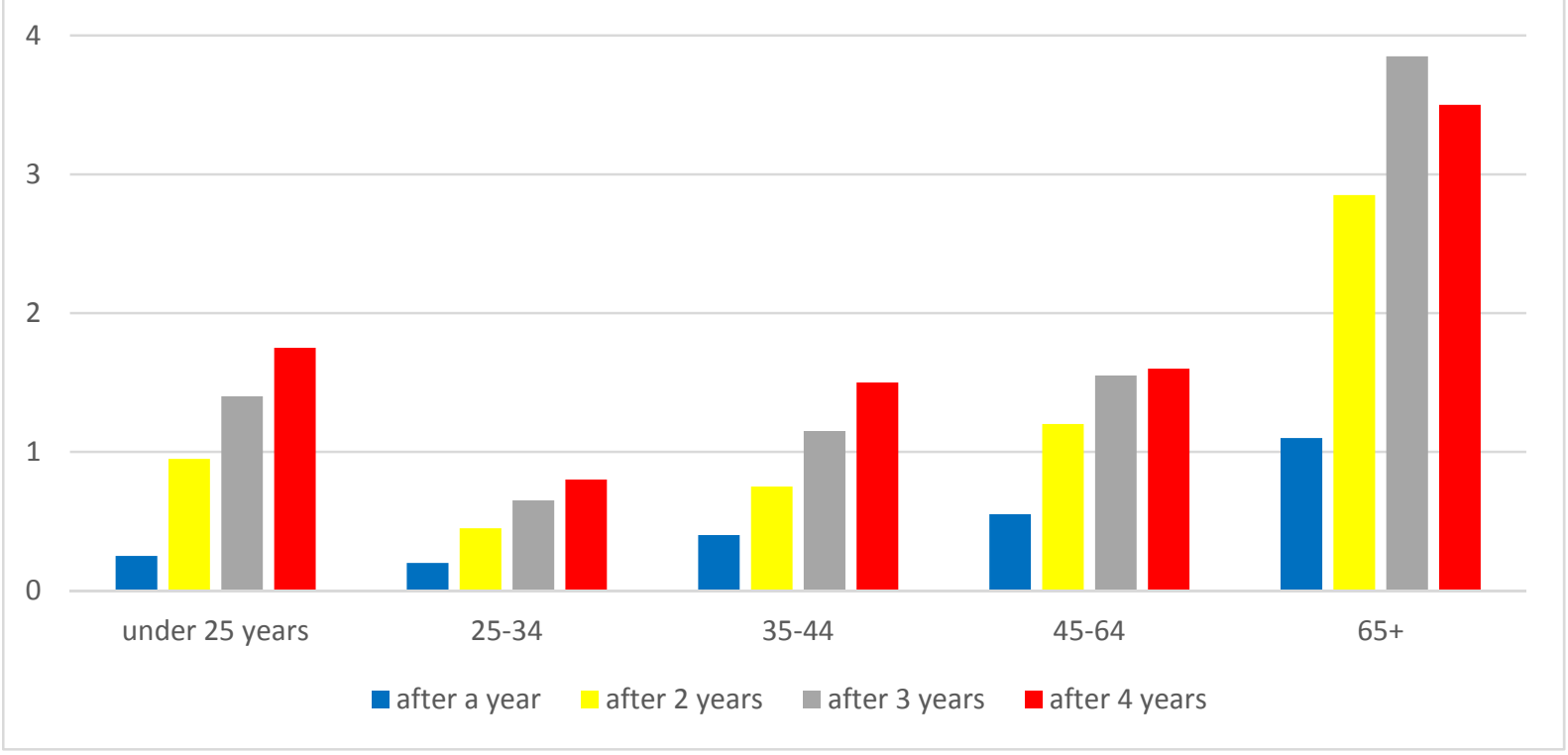

Fig. 3. Share of mortgage loans with late repayment of over 90 days in the number of mortgages granted in 2011, in subsequent years after granting according to the borrowers' age (vintage). Source: Kredyt Trendy 2015, No. 9.

Analysts from the Economic Information Bureau (Biuro Informacji Gospodarczej) indicate similar results, and in their newest report on people who are late in repaying loan obligations (InfoDług, 2015), report that approximately $1 / 3$ of the value of total outstanding financial obligations pertains to the debt of those who are over 55 years in age, and that every third person having problems with servicing debt is a borrower at the age of over 55 (Fig. 4). It, therefore, turns out that the demographic structure of society, including its aging process, has also an economic and financial dimension (further described by, i.a.: FORYŚ I., 2011).

Moreover, by precisely defining the so-called target borrower in regulations regarding the earliermentioned programs of financially supporting the purchase of an own apartment, the legislator, de facto, shapes the age sand social structure of the beneficiaries of such aid. Resources of the Family on 
its Own program targeted married couples and single parents bringing up at least one child and, after changing the laws in 2011, so-called "singles" (Act 2012, ...), whereas in the Apartment for the Youth program, for young people up to the age of 35 (Act on State Aid..., 2013). Data from the National Economy Bank (Bank Gospodarstwa Krajowego) reveal, i.a. that the largest group of beneficiaries of the Family on its Own program are people aged between 30 and 34 (approx. 42\%), and 25-29 (close to 28\% of total beneficiaries; Fig. 5).

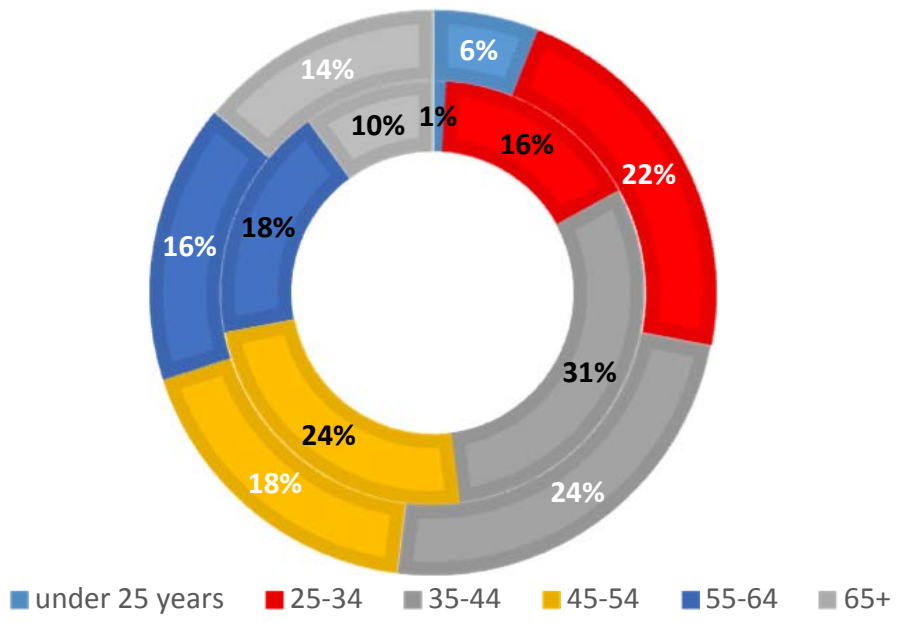

Black font is used to indicate the share of clients in debt according to the value of debt, white font - the share of those in debt according to the number of people.

Fig. 4. General structure of debt accounting for the age of the borrowers according to the value and number of people in debt (\%). Source: Polish report on outstanding debt and unreliable debtors (Ogólnopolski raport o zaległym zadłużeniu i niesolidnych dłużnikach), BIG, Warsaw December 2015, p. 14.

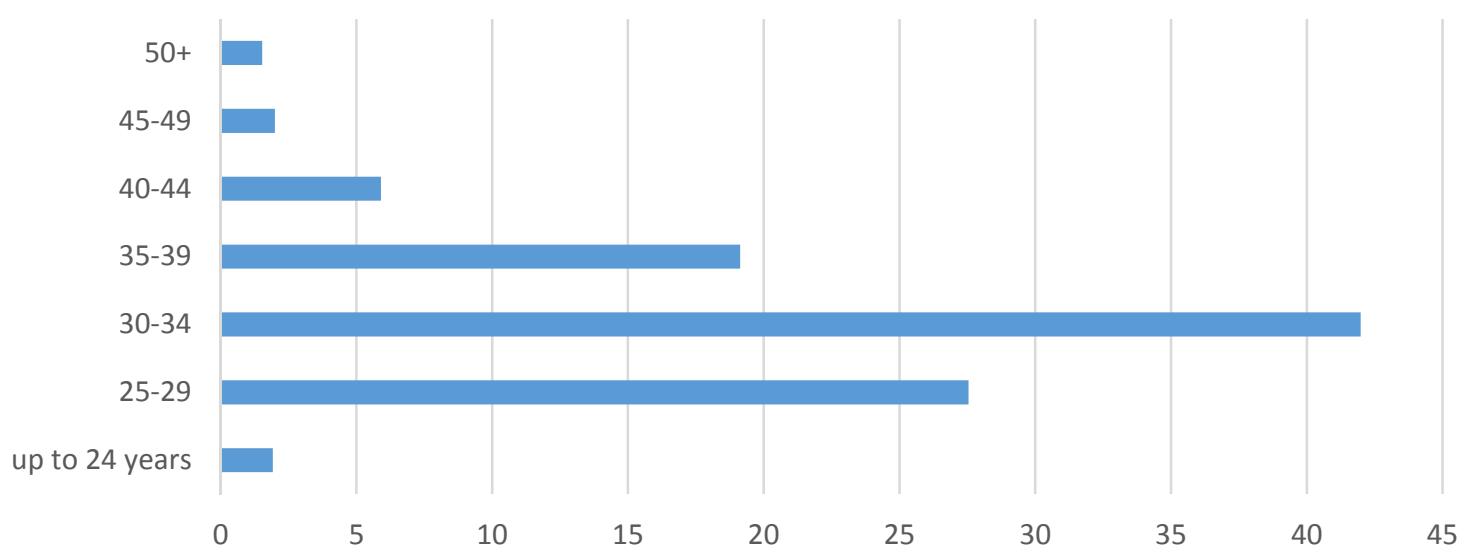

Fig. 5. Age of borrowers in the Family on its Own program, state as of 31.12.2013. Source: Family on its Own (Rodzina na Swoim)- numeric data for 31.12.2013; www.bgk.pl (25.01.2016).

\section{Summary}

The current, very competitive residential real estate market requires its participants to continuously monitor the dynamically occurring situation and the necessity of adapting to the changes taking place. One very important premise generating the need for the residential real estate market to transform are the demographic changes of society, without accounting for which it is difficult to imagine the functioning of, i.a. development companies dealing with housing supply or institutions financing their purchase. It turns out that new market determinants create new housing needs, which developers try to account for in their portfolios, dedicating at least a share of the offered areas to specific groups of clients with special, and not universal requirements. These types of projects are faced with higher investment risk (BROWN 2015, SIEMINSSKA 2013), but also a higher rate of return if they are well-suited to market expectations. 
The present paper indicated examples of building investment strategies assumed by selected development companies accounting for the changing market expectations that result from the demographic changes of the Polish society and the accompanying financial determinants. The faster and more accurately these entities adapt their action strategies, the better business result and position on the market they are likely to obtain. Moreover, due to the multi-directional, not only economic, dimension of structural changes of the Polish society, it is worth indicating the need for an extensive, interdisciplinary study of the consequences they carry, and thus assuming further research to deepen knowledge of the aspects raised in the work - studies o not only an economic but also interdisciplinary nature, including behavioral studies, connected with cultural anthropology or gerontology.

\section{References}

BELNIAK S., GŁUSZAK M., ZIĘBA M., 2013, Budownictwo ekologiczne. Aspekty ekonomiczne (Ecological Construction. Economic Aspects), Wydawnictwo Naukowe PWN, Warszawa (Polish Scientific Publishers PWN, Warsaw).

BGK, Bank Gospodarstwa Krajowego (National Economy Bank), www.bgk.pl (2.02.2016).

BŁASzCZAK G., 2016, Nie wystarczy dla wszystkich (Not Enough for Everyone) Rzeczpospolita dated 1.02.2016.

BŁASZCZAK G., KRZEŚNIAK-SAJEWICZ M., 2016, Banki będą mniej skłonne pożyczać na mieszkania (Banks will be Less Willing to Lend Money for Apartments) Rzeczpospolita dated 12.01.2016.

Brown P. H., 2015, How Real Estate Developers Think. Design, Profits, and Community, University of Pennsylvania Press.

BRZESKI W., KIREJCZYK K., KOZŁOWSKI E., 2015, Budownictwo senioralne w Polsce. Perspektywy rozwoju (Senior Construction in Poland. Development Perspectives), REAS.

DitTmann I. 2013. Primary and Secondary Residential Real Estate Markets in Poland - Analogies in Offer and Transaction Price Development, Real Estate Management and Valuation. Volume 21, Issue 1.

DONNER CH., 2000, Housing Policies in the European Union. Theory and Practice. Austrian Federal Ministry of Economic, Affaires and Labour. Vienna, December.

Eco-innovations in Cities, 2015, ed. SZELĄGOWSKA A., BRYX M., CeDeWu.pl, Warsaw.

EUROSTAT, 2012, Aktywność osób starszych i solidarność międzypokoleniowa, Statystyczny portret Unii Europejskiej 2012 (Actioness of the Elderly and Inter-Generational Solidarity, a Statistical Portrain of the European Union 2012),

FORYŚ I., 2011, Społeczno-gospodarcze determinanty rozwoju rynku mieszkaniowego w Polsce (Socio-economic Determinants of Residential Real Estate Maret Development, Uniwersytet Szczeciński, Szczecin.

GUS, Główny Urząd Statystyczny (Central Statistical Office), www.stat.gov.pl (23.01.2016).

HeinZe R.G., NAEgele G., 2009, "Silver Economy" in Germany - More Than Only the "Economic Factor: Old Age"!, Journal on Social \& Psychological Gerontology, No. 2.

http:/ / www.polskawliczbach.pl (25.01.2016).

IGLICKA-OKÓLSKA K., 2001, Poland's Post-War Dynamic of Migration, Asghate, Aldershot, London.

INFODŁUG, 2015, Ogólnopolski raport o zaległym zadłużeniu i niesolidnych dłużnikach (Polish National Report on Outstanding Debt and Unsound Debtors) BIG, Warsaw.

Inwestowanie $w$ mieszkania $w$ Polsce (Investing in Apartments in Poland), 2015, REAS, CMS LAW.TAX.

Innowacje w zarządzaniu miastami w Polsce (Innovations in Managing Cities in Poland), 2014, ed. BRYX M., SGH Warsaw.

Kompleksowa opieka nad pacjentem w wieku senioralnym, analiza dobrych praktyk (Complex Care of Elderly Patients, Analsyis of Good Practice), 2016, Raport EY (EY Report).

Kredyt Trendy (Credit Trends) 2015, No. 9, BIK Warsaw.

KRÜGER C., 2016, Diskurse des Alter(n)s. Öffentliches Sprechen über Alter in der Bundesrepublik Deutschland. [eng. Discourses of Age(ing): Public Speaking about Age in the Federal Republic of Germany], DE GRUYTER MOUTON.

KUCHARSKA - STASIAK, E., 2006, Nieruchomość w gospodarce rynkowej (Real Estate in National Economy), PWN, Warsaw.

LuMBY S., 1998, Investment Appraisal and Financial Decisions, International Thomson Business Press, London.

LuSARdi A., Mitchell O.S., 2007, Baby Boomer Retirement Security: The Roles of Planning, Financial Literacy, and Housing Wealth, Journal of Monetary Economics, Volume 54, Issue 1. 
ŁASZEK J., AUGUSTYNIAK H., OlSZEWSKI K., WASZCZUK J., 2015, Informacja o cenach mieszkań $i$ sytuacji na rynku nieruchomości mieszkaniowych i komercyjnych w Polsce w III kwartale 2015 r. (Information on Prices of Apartments and the Situation on the Residential and Commercial Real Estate Market in the III Quarter of 2015), NBP.

Małżeństwa oraz dzietność w Polsce (Marriages and fertility rates in Poland), 2016, Główny Urząd Statystyczny (Central Statistical Office), Warsaw.

MANSFIElD E., 1980, Economics Principles, Problems, Decisions, WW Norton \& Company, New York.

MCFADDEN D.L., 1994, Demographics, the Housing Market, and the Welfare of the Elderly, Studies in the Economics of Aging, National Bureau of Economic Research, http:/ / www.nber.org/chapters/c7346 (2.02.2016).

NBP, Narodowy Bank Polski (National Bank of Poland), www.nbp.pl (25.01.2016).

Ogólnopolski raport o kredytach mieszkaniowych i cenach transakcyjnych nieruchomości z 2011 i 2015 r (Polish National Report on Housing Loans of 2011 and 2015), AMRON-SARFiN, www.zbp.pl (25.01.2016).

Philipov D., Goujon A., Di GIUliO P., Ageing Dynamics of a Human-Capital-Specific Population: A Demographic Perspective, Demographic Research, Vol. 31, art. 44, pp. 1311-1336.

Prognoza ludności Polski na lata 2014-2050 (Population Forecast for the years 2014-2050), 2014, Główny Urząd Statystyczny (Central Statistical Office), Warsaw.

Raport o sytuacji banków w I pótroczu 2015 r. (Report on Situations of Banks in I half-year of 2015) 2015, UKNF, Warsaw

REKOMENDACJA S dotyczaca dobrych praktyk w zakresie zarządzania ekspozycjami kredytowymi zabezpieczonymi hipotecznie (RECOMMENDATION S regarding good practice in terms of managing credit expositions secured by mortgage), 2013, KOMISJA NADZORU FINANSOWEGO (Polish Financial Supervision Authority).

Rodzina na swoim - dane liczbowe na 31.12.2013 r.; www.bgk.pl (25.01.2016).

RUDNICKA M., SURDEj A., 2013, Gospodarka senioralna. Nowy sektor gospodarki narodowej w Polsce (Senior Economy. A New Sector of National Economy in Poland) Centrum im. Adama Smitha (Adam Smith Center), Warsaw.

Rynek gruntów inwestycyjnych w Polsce (Invesment Land Property Market in Poland), 2015, JLL, Warsaw.

Seniorzy w województwie opolskim - szanse i wyzwania (Seniors in Opolskie Voivodeship - Opportunities and Challenges), 2014, Urząd Marszałkowski Województwa Opolskiego, Opole.

SIEMIŃSKA E., 2012, Nowe wyzwania inwestowania i finansowania projektów deweloperskich (New Challenges of Investing and Financing Developer Projects), Studia i Materiały Towarzystwa Naukowego Nieruchomości (Journal of the Polish Real Estate Scientific Society), TNN Olsztyn, Vol. 20 No. 3.

SIEMIŃSKA E., 2013, Ryzyka inwestowania i finansowania na rynku nieruchomości w kontekście etyki $i$ społecznej odpowiedzialności (Investment and Financing Risks on the Real Estate Market in the Context of Ethics and Social Responsibility) Uniwersytet Mikołaja Kopernika (Nicolaus Copernicus Univserity), Torun.

ŚmietanA K., 2014, Diversification Principles of Real Estate Portfolio, Real Estate Management and Valuation, Vol. 22, No. 1.

USTAWA z dnia 27 września 2013 r. o pomocy państwa w nabyciu pierwszego mieszkania przez młodych ludzi (Act of 27 September 2013 on state aid in obtaining a first apartment by young people), t.j. Dz.U. (Journal of Laws) 2015, No. 1865.

USTAWA z dnia 8 września 2006 r. o finansowym wsparciu rodzin i innych osób w nabywaniu własnego mieszkania (Act of 8 September 2006 on financial support for families and other people in obtaining their first apartment) , t.j. Dz.U. (Journal of Laws) 2012, No. 90 as ammended.

VOICU, C., SEILER, M. J., 2013, Understanding Systematic Risk in Real Estate Markets, Journal of Housing Research, 22(2).

Wynajem mieszkań przez inwestorów instytucjonalnych (Rental of Apartments by Institutional Investors) 2013, PWC, REAS, CMS. 